\title{
SERVICE QUALITY IN THE PUBLIC SERVICE OF LATVIA
}

\author{
Iveta Katelo \\ Daugavpils University, Latvia \\ Irēna Kokina \\ Daugavpils University, Latvia \\ Vitālijs Raščevskis \\ Daugavpils University, Latvia
}

\begin{abstract}
Improvement of quality of public services is one of the important goals in the advancement of the operation of state / public administration in Latvia. The aim of the research was to evaluate the quality of customer service in the institutions of public administration in Latvia, to perform the factor analysis of the collected data.

The research was based on the selection of customers of public services, in total of 292 people in Riga and in Latvian regional centres in 2017-2018. The research was conducted in public institutions of Latvian regions that provide social assistance (SSIA - the State Social Insurance Agency), offer employment promotion services (SEA - the State Employment Agency); realize tax policy in the state (SRS - the State Revenue Service), implement the state environmental protection policy (MEPRD - Ministry of Environment Protection and Regional Development); provide legal aid services (DC - Daugavpils Court). The quality of services provided to the clients of corresponding institutions was evaluated. For the data collection, the service quality assessment model - the SERVQUAL instrument (Parasuraman et al., 1988) was used, as well as the analysis of the research data factors was carried out.

The service quality assessment revealed that the performance of public service organizations in Latvia does not meet the customers' expectations. The evaluation of service quality provided by public authorities, as well as their regular monitoring would improve the quality of services provided.
\end{abstract}

Keywords: factor analysis, public sector, service quality, SERVQUAL.

\section{Introduction}

One of the most important trends in the global economy today is the growing role of the service sector. This is evidenced by the increase in the level of production of services compared to the production of materials, by significant growth in the range of offered services, as well as by the increase in the number of people employed in the service sector. 
This trend is especially visible in the countries with developed socioeconomic system, where the proportion of services in the GDP is currently around $70 \%$. In Latvia, the proportion of services in the GDP according the benefit of branches reached 73.6\% in 2019 (Central Statistical Bureau of Latvia, 2020). At present, the service sector is being receiving increasing attention, taking into account its role in the socioeconomic development of society. Public services designed to meet the needs of citizens have a special place in this field. The improvement of the quality of public services is one of the important goals in the advancement of the operation of state / public administration in Latvia and in the world.

Public services are a "tangible result" of the activities of public administration or local government institutions, which manifests itself in providing certain services to its customers - the society. Public services, along with the direct implementation of power and state commercial activity, are considered to be one of the ways of implementation of public functions (Katelo, Kokina, \& Raščevskis, 2019).

The aim of the research was to evaluate the quality of customer service in public administration institutions of Latvia and to perform the factor analysis of the collected data.

The research was based on the selection of public service customers, in total 292 people in Riga and Latvia regional centres in Valmiera, Ventspils, Jelgava, and Daugavpils in 2017-2018. The research was conducted in the state institutions of Latvian regions that provide social assistance (SSIA), offer employment promotion services (SEA); implement the tax policy in the state (SRS), implement the state environmental protection policy (MEPRD); provide legal aid services (Daugavpils Court). The quality of services provided to the clients of corresponding institutions was evaluated.

The respondents were inquired at the locations of rendering public services. The respondents were introduced to the content and purpose of the poll. Before providing the data, the respondents' anonymity was guaranteed. The research took into account ethical and legal principles to ensure that the research participants' personal rights were not violated. In the research, a service quality assessment model - the SERVQUAL research instrument (Parasuraman et al., 1988) was used, as well as the analysis of the collected data factors was carried out. The quality of service is assessed by calculating the difference between the quality expected by the customer, and the quality that he/she receives and the quality provided. The SERVQUAL questionnaire is structured in two parts. Each part each includes 22 questions to assess customer expectations and the quality of the service received. Service quality assessment is obtained by comparing customer expectations and perceived quality values. The factor analysis is a technique of data reduction that uses the correlation between data 
variables. When conducting factor analysis, it is assumed that there are some basic factors that explain the correlations or mutual relations between the observed variables (Chatfield \& Collins, 1992).

\section{Literature Review}

The improvement of the quality of public services is one of the most important goals in the enhancement of public administration around the world, therefore, the issues of the quality of public services have been analysed by many foreign researchers.

Quality management in the Turkish public sector has been analysed by S. Coskun (Coskun, 2002). Quality management has been on the agenda of the activities of state / public administration of Turkey since 1990. In the context of the Turkish public sector, quality management is identified not only as a governance approach and system for improving the quality of public services, but also as a tool for solving the challenges of Turkey's state administration. The results of a survey conducted in two ministries show that employees of both ministries had positive attitudes towards quality management. The majority of the respondents agreed to the necessity and usefulness of quality management in the public sector of Turkey. Most of the respondents also agreed with the definition of quality management as "a governance approach aimed at customer satisfaction through continuous improvement of the provided services and processes".

Opportunities to improve the quality of services in the public sector of Great Britain have been described by C.S. Williams and M.N.K. Saunders (Williams \& Saunders, 2008). The authors proposed alternative versions for the determination of service quality that can help to improve the performance of public service providers. The authors appealed to public sector managers to create a tool for the assessment of changes in service quality and for setting down priorities.

A research about the relationship between service quality and customer behaviour in Spain has been conducted by M. Sanchez-Perez, J.C. GazquesAbad, and R. Sanchez Fernandez (Sanchez-Perez, Gazques-Abad, \& Sanchez Fernandez, 2007). The research identifies five different research directions in the study of service quality, analyses the interconnection between service quality and customer intentions. The research confirms the relationship between the five dimensions of service quality, as well as customer behaviour and intentions, provides a useful guide for the investigation of service quality by offering a scale for measuring service quality in the public sector.

A research on service quality in the public sector of Malaysia was performed by M.H. AbdRashid (AbdRashid, 2008). The research identified a 
number of shortcomings in the public sector where improvements should be made. The employees of customer service were rated the lowest. The survey showed that customer service staffs had poor communication skills; they were not customer friendly, inefficient; they were not sufficiently informed about the product and the service standards to be able to qualitatively perform their task.

Quality management of public services in Finland has been studied by V. Tuomi (Tuomi, 2012). According to this research, public sector organizations do not fully implement quality control. The main problem is that organizations do not regularly evaluate the quality of services, and after the evaluation do not further develop their activities, do not improve the quality of services. There are no practical obstacles that could hinder the implementation of quality management in the public sector. Organizations should strive to apply it in their operating environment.

A research on the development and current situation of state / public administration in Poland has been carried out by S. Mazur, M. Moždzen and M. Oramus (Mazur, Moždzen, \& Oramus, 2018). This publication has been produced for the European Commission with the technical assistance of the European Institute of Public Administration (EIPA). The report highlights the following key areas for improvement: 1. Improving the trust in the civil service and its image. Raising public understanding of the benefits of the civil service and its role, focusing on the needs of citizens and modern means of communication. 2. Quality of management and human resources in the civil service. The systems and management standards used by the offices need to be modernized to provide more flexibility in human resource management through a long-term plan. 3. Remuneration levels and appointment restrictions in the civil service. The relatively low salaries in the civil service, combined with the appointment restrictions cause the risk that highly qualified civil servants may leave the organizations, as well as make more it difficult to attract new specialists to replace them.

The quality of public services in the cities of Egypt in comparison with Malaysia has been studied by Mona Ali (Ali, 2012). The research has revealed that customer satisfaction with the dimensions of material gain / tangibles and empathy in service quality makes the greatest contribution. The researcher has concluded that the providers of public service should be informed about the results of the research in order for them to make changes and improvements in the quality of the services provided.

The quality of public services in Taiwan has been analysed by Chih-Tung Hsiao (Chih-Tung Hsiao, 2008). The research focused on the customer-oriented service system and behaviour of service providers that is widespread in the public sector. Public sector organizations should pay more attention to staff training and skills development, so that they understand the public service. 
In Latvia, the issues of service quality have been studied by several scholars. The organizational and economic possibilities of quality control have been researched by L. Melece (Melece, 2004). J. Eglītis (Eglītis, 2003) has worked on the development of a quality assurance system in the field of education. The quality assessment model for ensuring the quality of education services in rural consultation centres has been developed by G. Grīnberga-Zālīte (Grīnberga-Zalīte, 2011). The importance of the customer-oriented approach in the development of public administration in Latvia has been studied by R. Putāns (Putāns, 2016). The quality of public services in local authorities of Lithuania has been evaluated by G. Kondrotaite (Kondrotaite, 2012).

\section{Methodology}

A model of service quality assessment - the SERVQUAL research instrument (Parasuraman et al., 1988) was adapted and practically tested in this research. A copy of the SERVQUAL questionnaire was obtained from the version included in the work (Parasuraman et al., 1988). The suitability of the SERVQUAL method to the process of assessment of the quality of public services was verified, at the same time experimenting with the formulation of survey questions and the valuation scale of SERVQUAL. A research model was developed, and the research questionnaire was translated into Latvian. The research model and the questionnaire were approbated with a small number of customers and then modified to suit the target audience.

The research was based on a selection of public service customers in the largest cities of Latvia - Riga, Daugavpils, Jelgava, Ventspils, and Valmiera. Two hundred and ninety-two randomly selected representatives of the selection filled in the SERVQUAL questionnaire.

The questionnaire of the SERVQUAL method consisted of two parts. Each part of the questionnaire contained 22 statements about the quality of service, which formed a set of 5-dimensional criteria. The respondents had to rate each statement according to the 5-level Likert-type scale.

Part A showed the customer's expectations regarding the service quality as well as the importance of various quality criteria for the customer.

Part B displayed the assessment of the service received by the customer.

The object to be assessed in the questionnaires was service quality as a set of five quality dimensions, 22 criteria, in which:

Dimension 1 - Set of tangibles (appearance and physical facilities);

Dimension 2 - Reliability (trustfulness, accurate performance);

Dimension 3 - Responsiveness (doings and the willingness to help);

Dimension 4 - Competence (attention, credibility); 
Dimension 5 - Empathy (convenient receiving of service, good communication and customer understanding).

For processing the research data, a factor analysis method was used. Factor analysis is a data reduction technique that uses correlations between data variables. When performing factor analysis, it is assumed that there are some basic factors, which explain the correlations or interrelationships between the observed variables (Chatfield \& Collins, 1980). Factor analysis has been widely used by many researchers in the field of economics, marketing, sociology, and education (Nimako et al., 2012; Bollen, 1989; Doll et al., 1994; Li et al., 2013).

\section{Results}

In order to provide general information about the respondents, the SPSS 22.0 - Statistics Package for the Social Sciences - was used for the analysis of the collected data. The general characteristics of the respondents include their gender, age, level of education and employment. In total, 292 respondents participated in the survey. 214 women participated in the survey, which makes $73.3 \%$, and 78 men $(26.7 \%)$, see Table 1.

Table 1 Research Respondents by Gender

\begin{tabular}{|c|c|c|c|c|}
\hline & Frequency & $\%$ & Credibility \% & Cumulative \% \\
\hline Women & 214 & 73,3 & 73,3 & 73,3 \\
Men & 78 & 26,7 & 26,7 & 100,0 \\
Total & 292 & 100,0 & 100,0 & \\
\hline
\end{tabular}

Source: The table created by the authors, statistical results of the survey, 2019.

According to age, the respondents of the research were divided into three groups: 20-40 years, $41-60$ years, $60<$ years. There were 101 respondents aged $20-40$, who made $34.6 \%$ of the total number of the respondents; the age group 41-60 was represented by 132 respondents, i.e. $45.2 \%$ of the total number of the respondents; whereas, the age group $60<$ included 59 respondents, who mad $20.2 \%$ of the total number of the respondents, see Table 2 .

The level of education of the respondents of the survey was different. The respondents participating in the research had various education backgrounds the respondents with higher education were the majority - 165 people, respectively - $56.5 \%$ of the total number of the respondents; the respondents with secondary special education - 101 people, secondary education - 26 people, i.e. $8.9 \%$ of the total number of the respondents, see Table 3. 
Proceedings of the International Scientific Conference. Volume VI, May $28^{\text {th }}-29^{\text {th }}$, 2021. 293-311

Table 2 Age Distribution of the Survey Respondents

\begin{tabular}{|c|c|c|c|c|}
\hline & Frequency & $\%$ & Credibility \% & Cumulative \% \\
\hline $20-40$ & 101 & 34,6 & 34,6 & 34,6 \\
$41-60$ & 132 & 45,2 & 45,2 & 79,8 \\
$60<$ & 59 & 20,2 & 20,2 & 100,0 \\
Total & 292 & 100,0 & 100,0 & \\
\hline
\end{tabular}

Source: The table created by the authors, statistical results of the survey, 2019.

Table 3 Level of Education of the Survey Respondents

\begin{tabular}{|c|c|c|c|c|}
\hline & Frequency & $\%$ & Credibility \% & Cumulative \% \\
\hline $\begin{array}{c}\text { Secondary education } \\
\text { Secondary special } \\
\text { education }\end{array}$ & 26 & 8,9 & 8,9 & 8,9 \\
$\begin{array}{c}\text { Higher professional/ } \\
\text { vocational education } \\
\text { Total }\end{array}$ & 101 & 34,6 & 34,6 & 43,5 \\
& 292 & 56,5 & 56,5 & 100,0 \\
\hline
\end{tabular}

Source: The table created by the authors, statistical results of the survey, 2019.

The research also identified the respondents' employment. 208 employees representing $71.28 \%$ of the total number, 47 pensioners/retired persons $(15.96 \%)$ and 37 unemployed persons $(12.77 \%)$ were involved in the research.

Further the results of the researches carried out in 2017-2018 are analysed. Their statistical analyses have revealed the following results.

The results of the Cronbach`s Alpha coefficient of this research are shown below, indicating a high internal consistency of the data (see Table 4).

Table 4 Cronbach's Alpha of the Research

\begin{tabular}{|c|c|}
\hline $\begin{array}{c}\text { Dimensions of customer } \\
\text { satisfaction }\end{array}$ & Cronbach's Alpha \\
\hline Dimension of tangibles & 0.761 \\
\hline Dimension of reliability & 0.745 \\
\hline Dimension of responsiveness & 0.787 \\
\hline Dimension of competence & 0.631 \\
\hline Dimension of empathy & 0.813 \\
\hline
\end{tabular}

Source: The table created by the authors, statistical results of the survey, 2019.

According to Bryman \& Bell (Bryman \& Bell, 2011), Coefficient Alpha may vary in the range from 1 , which shows perfect internal reliability, to 0 , which, in turn, indicates the data without internal reliability. As shown in Table 4 , for all measurements included in the research, the coefficient was 0.7 and 
above, indicating an acceptable degree of internal confidence of the measuring tool.

The average value of evaluation of service expected by customers is 4.47. The results of the evaluation of the expected service are shown in Table 5. Comparing with the data of similar studies in Egypt and Malaysia, it must be concluded that the expectations of Latvian customers about the service are lower (see Table 5).

Table 5 Characterization of Evaluation of Service Expected by Customers

\begin{tabular}{|c|c|c|c|c|c|c|c|}
\hline \multirow[b]{2}{*}{$\begin{array}{c}\text { Dimensions of } \\
\text { quality }\end{array}$} & \multicolumn{2}{|c|}{$\begin{array}{c}\text { Number of } \\
\text { questionnaires }\end{array}$} & \multirow[b]{2}{*}{$\begin{array}{c}\text { Averag } \\
\text { e }\end{array}$} & \multirow[b]{2}{*}{ Median } & \multirow[b]{2}{*}{ Mode } & \multirow{2}{*}{$\begin{array}{c}\text { Average } \\
\text { expected } \\
\text { service in } \\
\text { Egypt } \\
\text { (2012) }\end{array}$} & \multirow{2}{*}{$\begin{array}{c}\text { Average } \\
\text { expected } \\
\text { service } \\
\text { in Malaysia } \\
\text { (2012) }\end{array}$} \\
\hline & Credible & Lost & & & & & \\
\hline Tangibles & 292 & 0 & 4,1575 & 4,2500 & 5,00 & 6,029 & 4,69 \\
\hline Reliability & 292 & 0 & 4,7301 & 5,0000 & 5,00 & 6,194 & 5,81 \\
\hline Responsiveness & 292 & 0 & 4,6986 & 5,0000 & 5,00 & 6,181 & 4,67 \\
\hline Competence & 292 & 0 & 4,5325 & 4,7500 & 5,00 & 6,217 & 4,81 \\
\hline Empathy & 292 & 0 & 4,2363 & 4,4000 & 5,00 & 5,836 & 5,73 \\
\hline Total & 292 & 0 & 4,4721 & 4,5909 & 5,00 & 6,091 & 5,142 \\
\hline
\end{tabular}

Source: The table created by the authors, statistical results of the survey by using SPSS22.00, 2019, according to Ali, 2012.

The average evaluation value of the perceived service is 3.98. The results of the customer perceived service evaluation are shown in Table 6.

Table 6 Characterization of Evaluation of Service Perceived by Customers

\begin{tabular}{|c|c|c|c|c|c|c|c|}
\hline \multirow[b]{2}{*}{$\begin{array}{l}\text { Dimensions of } \\
\text { quality }\end{array}$} & \multicolumn{2}{|c|}{$\begin{array}{c}\text { Number of } \\
\text { questionnaires }\end{array}$} & \multirow[b]{2}{*}{ Average } & \multirow[b]{2}{*}{ Median } & \multirow[b]{2}{*}{ Mode } & \multirow{2}{*}{$\begin{array}{l}\text { Average } \\
\text { perceived } \\
\text { service } \\
\text { in Egypt } \\
\text { (2012) }\end{array}$} & \multirow{2}{*}{$\begin{array}{c}\text { Average } \\
\text { perceived } \\
\text { service } \\
\text { in Malaysia } \\
\text { (2012) }\end{array}$} \\
\hline & $\begin{array}{c}\text { Credibl } \\
\mathrm{e}\end{array}$ & Lost & & & & & \\
\hline Tangibles & 292 & $\overline{0}$ & 3,9486 & 4,0000 & $\overline{5,00}$ & 3,172 & 4,23 \\
\hline Reliability & 292 & 0 & 4,0616 & 4,2000 & 5,00 & 3,521 & 5,26 \\
\hline Responsiveness & 292 & 0 & 4,0728 & 4,0000 & 5,00 & 3,700 & 4,23 \\
\hline Competence & 292 & 0 & 4,0146 & 4,0000 & 5,00 & 3,576 & 4,40 \\
\hline Empathy & 292 & 0 & 3,8479 & 3,8000 & 5,00 & 3,124 & 5,30 \\
\hline Total & 292 & 0 & 3,9860 & 4,0000 & 5,00 & 3,418 & 4,68 \\
\hline
\end{tabular}

Source: The table created by the authors, statistical results of the survey by using SPSS22.00, 2019, according to Ali, 2012. 
The lowest evaluation of the service performance in the institutions of the public sector of Latvia was awarded to the $5^{\text {th }}$ quality dimension - empathy, 3.84 points on average, and the highest - to the $3^{\text {rd }}$ quality dimension responsiveness, 4.07 points on average. Comparing the data of similar studies carried out in Egypt and Malaysia, it must be concluded that the Latvian customers' evaluation of the perceived service is average high (see Table 6).

By calculating the difference between the values of the service perceived by customers and the service expected by customers, we obtain the average quality of rendering of service, which is evaluated negatively in all quality dimensions. The quality dimensions of safety, responsiveness, competence was assessed with -0.668 points, -0.626p., - 0.518p., accordingly. A less negative assessment of quality is observed only in the dimensions of tangibles (-0.209p.), and empathy (-0.388p.) (see Table 7).

Table 7 Average Quality of Public Services in Latvia in 2017-2018 (in points)

\begin{tabular}{|l|l|l|l|l|l|}
\hline $\begin{array}{l}\text { Dimension of } \\
\text { quality }\end{array}$ & $\begin{array}{l}\text { Average } \\
\text { evaluation } \\
\text { of the } \\
\text { service } \\
\text { expected (E) }\end{array}$ & $\begin{array}{l}\text { Average } \\
\text { evaluation } \\
\text { of the } \\
\text { service } \\
\text { received }(\mathrm{P})\end{array}$ & $\begin{array}{l}\text { Average } \\
\text { service } \\
\text { quality } \\
(\mathrm{P}-\mathrm{E})\end{array}$ & $\begin{array}{l}\text { Average } \\
\text { service } \\
\text { quality } \\
\text { in Egypt } \\
(2012)\end{array}$ & $\begin{array}{l}\text { Average } \\
\text { service } \\
\text { quality } \\
\text { in Malaysia } \\
(2012)\end{array}$ \\
\hline Tangibles & 4,1575 & 3,9486 & $-0,2089$ & $-2,857$ & $-0,09$ \\
\hline Security & 4,7301 & 4,0616 & $-0,6685$ & $-2,673$ & $-0,11$ \\
\hline Responsiveness & 4,6986 & 4,0728 & $-0,6259$ & $-2,481$ & $-0,09$ \\
\hline Competence & 4,5325 & 4,0146 & $-0,5179$ & $-2,641$ & $-0,08$ \\
\hline Empathy & 4,2363 & 3,8479 & $-0,3884$ & $-2,712$ & $-0,09$ \\
\hline Total & 4,4721 & 3,9859 & $-0,4861$ & $-2,672$ & $-0,09$ \\
\hline
\end{tabular}

Source: the able created by the authors, statistical results of the survey, 2019, according to Ali, 2012.

Analysing the survey results of the customers of the surveyed public institutions, it is obvious that the most positive evaluation of the quality of the provided services has been given by the customers of DREB (Daugavpils Regional Environmental Board) (from 0.147p. to 0.424p.). The most negative assessment of the quality of provided services has been given by the customers of SEA (from -0.278p. to -0.922p.), SSIA (from -0.215p. to -0.882p.), SRS (from -0.217 to $-0.892 \mathrm{p}$.). Almost three times higher assessment of service quality has been received from the customers of Daugavpils Court (from 0.092p. to -0.323p.) and OCMA (Office of Citizenship and Migration Affairs) (from + 0.068p. to -4555p.).

In turn, analysing the results of service quality assessment according to the place of residence of the respondents, it is evident that the residents of Latgale Region have assessed service quality less negatively (from -0.159p. to -0.409p.). 
In the other analysed regional cities and Riga, service quality was assessed almost twice more negatively. In Riga, customers assessed the quality of public services in the range from - $0.144 p$. to -0.842p., in Valmiera - in the range from 0.275p. to -0.878p., in Ventspils - from -0.444p. to -0.819p.

\section{Table 8 Quality Assessment of Public Services in Latvia in 2017/2018, in Terms of the Public Institutions Considered}

\begin{tabular}{|l|l|l|l|l|l|l|}
\hline $\begin{array}{l}\text { Dimensions of } \\
\text { quality }\end{array}$ & $\begin{array}{l}\text { Average } \\
\text { assessment } \\
\text { of service } \\
\text { quality } \\
\text { SEA }\end{array}$ & $\begin{array}{l}\text { Average } \\
\text { assessment } \\
\text { of service } \\
\text { quality } \\
\text { SSIA }\end{array}$ & $\begin{array}{l}\text { Average } \\
\text { assessment } \\
\text { of service } \\
\text { quality } \\
\text { DREB }\end{array}$ & $\begin{array}{l}\text { Average } \\
\text { assessment } \\
\text { of service } \\
\text { quality } \\
\text { DC, NLS } \\
\text { Nat.Land } \\
\text { Survey }\end{array}$ & $\begin{array}{l}\text { Average } \\
\text { assessment } \\
\text { of service } \\
\text { quality } \\
\text { OCMA }\end{array}$ & $\begin{array}{l}\text { Average } \\
\text { assessment } \\
\text { of service } \\
\text { quality } \\
\text { SRS }\end{array}$ \\
\hline Tangibles & $-0,278$ & $-0,215$ & 0,162 & $-0,318$ & 0,068 & $-0,215$ \\
\hline Reliability & $-0,729$ & $-0,882$ & 0,080 & $-0,332$ & $-0,345$ & $-0,786$ \\
\hline $\begin{array}{l}\text { Responsi- } \\
\text { veness }\end{array}$ & $-0,922$ & $-0,750$ & 0,147 & $-0,323$ & $-0,455$ & $-0,662$ \\
\hline Competence & $-0,783$ & $-0,680$ & 0,221 & $-0,224$ & $-0,062$ & $-0,567$ \\
\hline Empathy & $-0,511$ & $-0,600$ & 0,424 & $-0,092$ & $-0,055$ & $-0,472$ \\
\hline $\begin{array}{l}\text { Average } \\
\text { quality of } \\
\text { service }\end{array}$ & $-0,642$ & $-0,636$ & 0,211 & $-0,254$ & $-0,174$ & $-0,548$ \\
\hline
\end{tabular}

Source: The table created by the authors, statistical results of the survey, 2019.

In different age groups, the quality of services was assessed most negatively by customers of retirement age (from -0.169p. to -0861p.). Respondents aged 20-40 gave a higher assessment of service quality (from -0.33p. to -0497p.).

Analysing the obtained results according to the gender of the respondents, it is apparent that service quality was assessed less negatively by men (from 0.029p. to -0672p.). Women have generally assessed service quality more negatively (from -0.296p. to -0.704p.). The dimension of tangibles, i.e. material benefits has been assessed less negatively.

Analysing the results of the survey according to the level of education of the respondents, it can be seen that service quality is most negatively assessed by the respondents with secondary professional education (from -0.121p. to $0.842 \mathrm{p}$.). Higher evaluation has been given by the respondents with secondary education (from 0.269p. to -0538p.).

Evaluating the results of the survey according to the employment of the respondents, it must be concluded that the most negative assessment of service quality has been reported by retired customers (from -0.35p. to-1.2p.). Higher evaluation was given by working respondents (from -0.261p. to -0.740p.) (see Table 9). 
Proceedings of the International Scientific Conference. Volume VI, May $28^{\text {th }}-29^{\text {th }}$, 2021. 293-311

Table 9 Evaluation of Quality of Public Services Depending on the Employment of the Respondents

\begin{tabular}{|l|c|c|c|}
\hline $\begin{array}{l}\text { Dimensions of } \\
\text { quality }\end{array}$ & $\begin{array}{l}\text { Average assessment of } \\
\text { service quality for } \\
\text { employees }\end{array}$ & $\begin{array}{l}\text { Average assessment of } \\
\text { service quality for } \\
\text { retired }\end{array}$ & $\begin{array}{l}\text { Average assessment of } \\
\text { service quality for } \\
\text { unemployed }\end{array}$ \\
\hline Tangibles & $-0,610$ & $-0,350$ & 0,420 \\
\hline Reliability & $-0,740$ & $-1,10$ & $-0,992$ \\
\hline Responsiveness & $-0,604$ & $-1,20$ & $-0,969$ \\
\hline Competence & $-0,502$ & $-0,942$ & $-0,813$ \\
\hline Empathy & $-0,460$ & $-0,620$ & $-0,450$ \\
\hline $\begin{array}{l}\text { Average quality } \\
\text { of service }\end{array}$ & $-0,521$ & $-0,855$ & $-0,644$ \\
\hline
\end{tabular}

Source: the table created by the authors, statistical results of the survey, 2019.

Comparing the evaluation of service quality reported by public service customers, service providers, and employees, it should be noted that the customers have assessed it more negatively (from -0.449p. to -0.596p.). Comparing with the data from similar researches in other European and Asian countries, it can be concluded that the performance of Latvian public sector is moderately low (see Table 10).

Table 10 Comparison of Public Service Quality in Latvia and Other Countries

\begin{tabular}{|l|c|c|c|c|c|}
\hline $\begin{array}{c}\text { Dimensions } \\
\text { of quality }\end{array}$ & $\begin{array}{c}\text { Average } \\
\text { assessment of } \\
\text { public service } \\
\text { quality in } \\
\text { Latvia } \\
2017 .-2018 .\end{array}$ & $\begin{array}{c}\text { Average evaluation of } \\
\text { the quality of } \\
\text { educational services } \\
\text { LRATC (Latvian Rural } \\
\text { Advisory and Training } \\
\text { Centre)in Latvia } \\
\text { 2009.-2010. }\end{array}$ & $\begin{array}{c}\text { Average } \\
\text { evaluation of } \\
\text { the quality of } \\
\text { post-sale } \\
\text { assistance } \\
\text { service in } \\
\text { Italy 1998. }\end{array}$ & $\begin{array}{c}\text { Average } \\
\text { assessment } \\
\text { of public } \\
\text { service } \\
\text { quality in } \\
\text { Egypt } \\
2012 .\end{array}$ & $\begin{array}{c}\text { Average } \\
\text { assessment of } \\
\text { public service } \\
\text { quality in } \\
\text { Malaysia } \\
2012 .\end{array}$ \\
\hline Tangibles & $-0,208$ & $-0,505$ & 1,3 & - & $-0,09$ \\
\hline Reliability & $-0,668$ & 0,367 & $-0,9$ & - & $-0,11$ \\
\hline $\begin{array}{l}\text { Responsi- } \\
\text { veness }\end{array}$ & $-0,625$ & 0,937 & $-0,2$ & $-2,673$ & $-0,09$ \\
\hline Competence & $-0,517$ & $-0,069$ & $-0,1$ & 2,641 & $-0,08$ \\
\hline Empathy & $-0,388$ & $-0,040$ & 0,7 & - & $-0,09$ \\
\hline $\begin{array}{l}\text { Average } \\
\text { quality of } \\
\text { service }\end{array}$ & $-0,486$ & 0,138 & 0,160 & - & $-0,09$ \\
\hline
\end{tabular}

Source: the table created by the authors, statistical results of the survey, 2019, according to Grīnberga-Zālìte, 2011; according to Ali, 2012; Franceschini, 1998. 
The research analyses the results obtained during the evaluation by public service customers of the quality of expected and perceived public services in Latvia. In the course of the research, it has been concluded that it is not possible to use the SERVQUAL method without applying it to the circumstances of each state/public institution considered.

The assessment of service quality has revealed that the performance of public service organizations in Latvia does not meet customer expectations. The quality of rendering the services has been assessed as negative in all dimensions of quality. Thus, the level of customer satisfaction with the performance of public services also is negative.

The results of this analysis show that the shortcomings of public service, identified in the evaluation should be eliminated. An important step in eliminating the shortcomings of service providers is the organization of regular customer surveys in order to promptly assess the quality of provided public services. The evaluation of the quality of services, provided by state / public authorities and regular monitoring thereof would improve the quality of provided services and thus also the customer satisfaction.

\section{Factor Analysis of Survey Data}

Factor analysis is a data reduction technique that uses correlations between data variables. When performing factor analysis, it is assumed that there are some basic factors that explain the correlations or interrelationships between the observed variables (Chatfield \& Collins, 1992). Factor analysis has been widely used by many researchers in the field of economics, marketing, sociology, and education (Nimako et al., 2012; Bollen, 1989; Doll et al., 1994; Li et al., 2002). Statistical data analysis for this research was performed following an approach similar to that used by April \& Pather (April \& Pather, 2008).

The Kaiser-Meyer-OlKin (KMO) test helps to measure the data adequacy for the analysis. Kaiser (Kaiser, 1974) recommended the use of data, which adequacy values exceed 0.5 . In this research, the data adequacy value is 0.835 , which falls in the range of medium to excellent adequacy. Consequently, we may be sure that the collected data are suitable for factor analysis. After reviewing the adequacy of the data, the authors have performed the data factor analysis to assess the factors, which are important for improving the quality of public services.

The results of the factor analysis for the evaluation of the service expected by customers are provided in Table 11. Factor analysis has been performed using the method of principal component analysis (PCA). As summarized in Table 11, the cumulative value (\%) of component analysis of the expected service is 60,676 . 
Proceedings of the International Scientific Conference. Volume VI, May $28^{\text {th }}-29^{\text {th }}$, 2021. 293-311

Table 11 Factors Analysis of Evaluation of the Service Expected by Customers

\begin{tabular}{|c|c|c|c|c|c|c|c|c|c|}
\hline \multirow[b]{2}{*}{$\begin{array}{l}\text { Compone } \\
\text { nt }\end{array}$} & \multicolumn{3}{|c|}{ Initial Eigenvalues } & \multicolumn{3}{|c|}{$\begin{array}{l}\text { Extraction Sums of } \\
\text { Squared Loadings }\end{array}$} & \multicolumn{3}{|c|}{$\begin{array}{l}\text { Rotation Sums of Squared } \\
\text { Loadings }\end{array}$} \\
\hline & Total & $\begin{array}{l}\% \text { of } \\
\text { Varianc } \\
\text { e }\end{array}$ & $\begin{array}{l}\text { Cumulati } \\
\text { ve } \%\end{array}$ & Total & $\begin{array}{l}\% \text { of } \\
\text { Variance }\end{array}$ & $\begin{array}{l}\text { Cumulati } \\
\text { ve } \%\end{array}$ & Total & $\begin{array}{l}\% \text { of } \\
\text { Variance }\end{array}$ & $\begin{array}{l}\text { Cumulati } \\
\text { ve } \%\end{array}$ \\
\hline 1 & 9,058 & 41,174 & 41,174 & 9,058 & 41,174 & 41,174 & 6,231 & 28,323 & 28,323 \\
\hline 2 & 1,805 & 8,202 & 49,376 & 1,805 & 8,202 & 49,376 & 3,728 & 16,945 & 45,268 \\
\hline 3 & |1,359 & 6,176 & 55,552 & 1,359 & 6,176 & 55,552 & 1,911 & 8,687 & 53,955 \\
\hline 4 & 1,127 & 5,124 & 60,676 & 1,127 & 5,124 & 60,676 & 1,479 & 6,721 & 60,676 \\
\hline 5 & ,898 & 4,080 & 64,756 & & & & & & \\
\hline 6 & ,832 & 3,780 & 68,536 & & & & & & \\
\hline 7 & ,775 & 3,523 & 72,059 & & & & & & \\
\hline 8 & ,682 & 3,098 & 75,157 & & & & & & \\
\hline 9 & ,606 & 2,753 & 77,910 & & & & & & \\
\hline 10 & ,553 & 2,515 & 80,424 & & & & & & \\
\hline 11 & ,528 & 2,402 & 82,826 & & & & & & \\
\hline 12 & ,484 & 2,198 & 85,024 & & & & & & \\
\hline 13 & ,459 & 2,087 & 87,111 & & & & & & \\
\hline 14 & ,422 & 1,920 & 89,031 & & & & & & \\
\hline 15 &, 405 & 1,839 & 90,870 & & & & & & \\
\hline 16 & ,386 & 1,755 & 92,626 & & & & & & \\
\hline 17 & ,336 & 1,528 & 94,153 & & & & & & \\
\hline 18 & ,327 & 1,486 & 95,639 & & & & & & \\
\hline 19 & ,283 & 1,287 & 96,927 & & & & & & \\
\hline 20 & ,244 & 1,109 & 98,036 & & & & & & \\
\hline 21 & ,226 & 1,027 & 99,063 & & & & & & \\
\hline 22 & ,206 & ,937 & 100,000 & & & & & & \\
\hline
\end{tabular}

Source: The table created by the authors, statistical results of the survey by using SPSS22.00, 2019.

While performing the factor analysis by means of the method of principal component analysis, four eigenvalues have been obtained, which yield the sum of total quadratic loads was more than 1 , with a percentage cumulative deviation of 60,676 in the case of evaluation of service expected by customers. The first factor explains $41.174 \%$ of the total dispersion. It should be understood that the first factor explains the relatively large amount of dispersion, while the following factors explain only a small amount of dispersion.

Table 12 shows that the evaluation data of the service expected by customers were divided into four groups according to the factors of service quality. The load of each factor was evaluated. To evaluate the results, it should be noted that a factor load, which is greater than 0.30 , is considered essential, 0.40 is considered important, and 0.50 or more is considered very significant. The authors have assumed in this research that only factors with the load above 
0.50 are considered significant (Hair, Black, Babin, \& Anderson, 2014) The higher is the factor coefficient / ratio, the more important it is for the customers' expectations concerning service quality (Pallant, 2007). In fact, the minimal values of factor coefficients range from 0.429 or more in this research, and such coefficient values are considered important for performing factor analysis.

Table 12 Total Dispersion of Evaluation Data of Service Expected by Customers

\begin{tabular}{|c|c|c|c|c|}
\hline & \multicolumn{4}{|c|}{ Component } \\
\hline & 1 & 2 & 3 & 4 \\
\hline RG_j_9 & $\sqrt{, 790}$ & & & \\
\hline RG_j_7 &, 768 & & & \\
\hline $\mathrm{RG}_{\mathrm{j}} \mathrm{j}_{-} 13$ & ,734 & & & \\
\hline $\mathrm{RG} \_\mathrm{j} \_8$ &, 719 & & & \\
\hline $\mathrm{RG}_{\mathrm{j}} \mathrm{j}$ 12 & ,709 & & & \\
\hline RG_j_6 & ,685 & & & \\
\hline RG_j_14 & ,682 & ,462 & & \\
\hline RG_j_15 & ,615 & , 466 & & \\
\hline RG_j_10 & ,611 & & & \\
\hline RG_j_11 &, 602 & & & \\
\hline $\mathrm{RG}_{\mathrm{J}} \mathrm{j}$ 5 & ,565 & & & \\
\hline RG_j_16 &, 518 &, 460 & & \\
\hline RG_j_4 &, 505 & & & \\
\hline $\mathrm{RG}_{\mathrm{j}} \mathrm{j}_{1} 19$ & & ,765 & & \\
\hline RG_j_18 & & ,747 & & \\
\hline RG_j_20 & &, 726 & & \\
\hline RG_j_17 &, 429 & ,666 & & \\
\hline RG_j_21 & &, 559 & & \\
\hline RG_j_1 & & &, 797 & \\
\hline RG_j_2 & & & ,791 & \\
\hline RG_j_3 & & & ,673 & \\
\hline RG_j_22 & & & & ,836 \\
\hline
\end{tabular}

Source: The table created by the authors, statistical results of the survey by using, SPSS22.00, 2019.

Factor group I, which is considered the most important by customers when assessing the expected service quality, includes factors related to such dimensions of service quality as reliability, responsiveness, competence. This group includes factors with the coefficient from 0.79 to 0.505 .

Factor group II, assessing the significance of factors, included the factors related to such dimension of service quality as empathy. This group includes factors with the coefficient from 0.765 to 0.559 . 
Assessing the significance of factors, only Factor group III comprises the factors related to the dimension of service quality of tangibles. This group includes factors with the coefficient from 0.797 to 0.673 .

The results of factor analysis for the evaluation of customer-perceived service quality are presented in Table 13 . Factor analysis was performed using the method of principal component analysis (PCA). As summarized in Table 13, the cumulative value (\%) of component analysis of the perceived service is 66,966 .

Table 13 Factor Analysis of Evaluation of Customer-perceived Service

\begin{tabular}{|c|c|c|c|c|c|c|c|c|c|}
\hline \multirow[b]{2}{*}{$\begin{array}{l}\text { Comp } \\
\text { onent }\end{array}$} & \multicolumn{3}{|c|}{ Initial Eigenvalues } & \multicolumn{3}{|c|}{$\begin{array}{l}\text { Extraction Sums of Squared } \\
\text { Loadings }\end{array}$} & \multicolumn{3}{|c|}{$\begin{array}{l}\text { Rotation Sums of Squared } \\
\text { Loadings }\end{array}$} \\
\hline & Total & \begin{tabular}{|l}
$\%$ of \\
Variance
\end{tabular} & \begin{tabular}{|l} 
Cumulat \\
ive $\%$
\end{tabular} & Total & $\begin{array}{l}\% \text { of } \\
\text { Variance }\end{array}$ & \begin{tabular}{|l|l}
$\begin{array}{l}\text { Cumulat } \\
\text { ive } \%\end{array}$ \\
\end{tabular} & Total & $\begin{array}{l}\% \text { of } \\
\text { Variance }\end{array}$ & \begin{tabular}{|l} 
Cumulat \\
ive $\%$
\end{tabular} \\
\hline 1 & 13,216 & 60,074 & 60,074 & 13,216 & 60,074 & 60,074 & 10,941 & 49,734 & 49,734 \\
\hline 2 & 1,516 & 6,892 & 66,966 & 1,516 & 6,892 & 66,966 & 3,791 & 17,232 & 66,966 \\
\hline 3 &, 880 & 4,001 & 70,967 & & & & & & \\
\hline 4 &, 681 & 3,097 & 74,065 & & & & & & \\
\hline 5 &, 628 & 2,854 & 76,919 & & & & & & \\
\hline 6 &, 554 & 2,516 & 79,435 & & & & & & \\
\hline 7 &, 481 & 2,188 & 81,623 & & & & & & \\
\hline 8 &, 424 & 1,929 & 83,552 & & & & & & \\
\hline 9 &, 414 & 1,882 & 85,434 & & & & & & \\
\hline 10 &, 390 & 1,771 & 87,205 & & & & & & \\
\hline 11 &, 368 & 1,672 & 88,877 & & & & & & \\
\hline 12 &, 331 & 1,503 & 90,380 & & & & & & \\
\hline 13 &, 326 & 1,480 & 91,860 & & & & & & \\
\hline 14 &, 285 & 1,297 & 93,157 & & & & & & \\
\hline 15 &, 250 & 1,138 & 94,295 & & & & & & \\
\hline 16 &, 243 & 1,104 & 95,399 & & & & & & \\
\hline 17 & 229 & 1,043 & 96,441 & & & & & & \\
\hline 18 & 200 &, 907 & 97,349 & & & & & & \\
\hline 19 &, 183 &, 830 & 98,179 & & & & & & \\
\hline 20 &, 156 &, 711 & 98,890 & & & & & & \\
\hline 21 &, 126 &, 574 & 99,464 & & & & & & \\
\hline 22 &, 118 &, 536 & 100,000 & & & & & & \\
\hline
\end{tabular}

Source: The table created by the authors, statistical results of the survey by using SPSS22.00, 2019. 
The first factor explains $60.074 \%$ of the total dispersion. It should be understood that the first factor explains the relatively largest amount of dispersion, while the succeeding factors explain only a small amount of dispersion.

Table 14 shows that the evaluation data of the service perceived by customers were divided into two groups according to their importance. Each factor loading was evaluated. The authors assumed in this research that only factor loading above 0.50 are considered significant (Pal, 1986; Pal \& Bagai, 1987; Hair, Anderson, \& Black, 2014). The higher is the factor coefficient, the more important it is in terms of customer-perceived service quality (Pallant, 2007). In fact, the minimum values of factor coefficients ranged from 0.429 or greater in this part of the research, and such coefficient values are considered important for performing factor analysis.

Table 14 Total Dispersion of Evaluation Data of Customer-perceived Service Quality

\begin{tabular}{|c|c|c|}
\hline & \multicolumn{2}{|c|}{ Component } \\
\hline & 1 & 2 \\
\hline r_j_12 & 874 & \\
\hline r_j_14 & ,856 & \\
\hline$r_{\text {_j}} j_{1} 13$ & ,855 & \\
\hline r_j_7 & |,832 & \\
\hline $\mathrm{r}_{\text {_j}}{ }_{1} 16$ & ,808 & \\
\hline r_j_15 & ,,787 & \\
\hline$r_{j} j_{1} 17$ & ,776 & \\
\hline r_j_9 & ,769 & \\
\hline r_j_11 & ,755 & \\
\hline $\mathrm{r}_{\mathrm{j}} 10$ & ,746 & \\
\hline r_j_21 &, 745 & \\
\hline r_j_8 & ,731 & \\
\hline r_j_19 & ,724 & \\
\hline r_j_20 & ,718 & \\
\hline r_j_6 & ,716 & \\
\hline r_j_18 & ,703 & ,404 \\
\hline$r \_j \_5$ & ,647 & ,415 \\
\hline r_j_4 &, 645 &, 533 \\
\hline r_j_22 & , 417 & \\
\hline r_j_2 & & ,898 \\
\hline r_j_1 & & ,888 \\
\hline$r$ r_j_3 & ,491 &, 579 \\
\hline
\end{tabular}

Source: the table created by the authors, statistical results of the survey by using SPSS22.00, 2019. 
Factor group I, which is considered the most important by customers when assessing the expected service quality, includes factors related to such dimensions of service quality as reliability, responsiveness, competence and empathy. This group included factors with a coefficient from 0.874 to 0.645 .

Factor group II, assessing the significance of factors, included the factors related to such dimension of service quality as the set of tangibles. This group included factors with a coefficient from 0.898 to 0.579 .

The comparison of the factor analysis performed for the data groups related to the evaluation of the service expected and perceived by the customers has showed that the most important dimensions of service quality for customers, the performance of which needs to be improved, are reliability, responsiveness, competence and empathy. Less important factors are those related to the dimension of tangibles.

\section{Conclusions}

The research analyses the results obtained as a result of the evaluation by public service customers of the quality of expected and perceived public services in Latvia. In the course of this research, it has been concluded that it is not possible to use the SERVQUAL method without applying it to the circumstances of each state/ public institution researched

The service quality assessment has revealed that the performance of public service organizations in Latvia does not meet customer expectations. The quality of rendering the services is assessed as negative in all dimensions of quality. Consequently, the level of customer satisfaction with the performance of public services also is negative.

The results of this analysis demonstrate that the shortcomings of public service, identified in the evaluation, need to be reduced. An important step in reducing the shortcomings of service providers is the development of regular customer surveys in order to promptly evaluate the quality of provided public services. The evaluation of the quality of services provided by state/ public authorities and regular monitoring thereof would improve the quality of services provided and thus also the customer satisfaction.

Factor group I, which is considered the most important by customers when assessing the expected service quality, includes factors related to such dimensions of service quality as reliability, responsiveness, competence. This group included factors with a coefficient from 0.79 to 0.505 .

Factor group II, according to importance, included factors related to such dimension of service quality as empathy. This group included factors with a coefficient from 0.765 to 0.559 . 
According to the significance of the factors, only Factor group III included the factors related to the dimension of service quality of tangibles. This group included factors with the coefficient from 0.797 to 0.673 .

Factor group I, which is considered the most important by customers when assessing the expected service quality, includes factors related to such dimensions of service quality as reliability, responsiveness, competence and empathy. This group included factors with the coefficient from 0.874 to 0.645 .

Factor group II, according to the significance of factors, included the factors related to such dimension of service quality as the set of tangibles. This group included factors with the coefficient from 0.898 to 0.579 .

The comparison of the factor analysis performed for the data groups related to the evaluation of the service expected and perceived by the customers shows that the most important dimensions of service quality for customers, the performance of which needs to be improved, are reliability, responsiveness, competence and empathy. Less important factors are the factor related to the dimension of material benefit.

\section{References}

AbdRashid, M. H. (2008). Measuring and Achieving Quality Customer Service: A Study on Public Sector in Malaysia. Doctoral thesis. School of Hospitality and Service Management, Rochester Institute of Technology: Rochester, New York.

Ali, M. (2012). Service quality in public services. A study of the public services in urban Egypt.

April, G. D., \& Pather, S. (2008).Evaluating Service Quality Dimensions within e-Commerce SMEs. The Electronic Journal Information Systems Evaluation, Volume 11, Issue 3, 109 - 124. Retrieved from: www.ejise.com

Bollen, K. A. (1989). Confirmatory Factor Analysis. Structural equations with latent variables. Wiley Online Library.

Bryman, A., \& Bell, E. (2011). Business Research Methods (3rd ed.). Oxford University Press: Oxford.

Central Statistical Bureau of Latvia. (2020). Statistical Yearbook of Latvia 2019. Riga.

Chatfied, C. (1992). Introduction to Multivariate Analysis. Chapman \& Hall.

Chatfied, C., \& Collins, A. J. (1980). Introduction to Multivariate Analysis. Springer: US.

Chih-Tung, H. (2008). A study of service quality in public sector. International Journal of Electronic Business Management, Vol. 6, No. 1, 29-37.

Coskun, S. (2002). Total quality management (TQM) in the Turkish public sector: The view of public employes on practices, impacts and problems for the implementation of TQM in two public organizations. Doctoral thesis. The Institute of Economics and Social Sciences of Bilkent University.

Doll, W., Xia, W., \& Torkzadeh, G. (1994). A Confirmatory Factor Analysis of the End-User Computing Satisfaction Instrument. MIS Quarterly, (18:4).

Eglitis, J. (2003). Regional and economical aspects of assuring the quality of education. Summary of doctoral thesis. Latvian Agricultural University: Jelgava. 
Franceschini, F., Cignetti, M., \& Caldara, M. (1998). Comparing tools for service quality evaluation. Science, Vol. 3, No. 4, 356-367.

Grīnberga-Zālīte, G. (2011). Assurance of customer-guided training services' quality at rural advisory centres. Summary of doctoral thesis. Latvian Agricultural University: Jelgava.

Hair, Jr. J. F., Black, W. C., Babin, B. J., \& Anderson, R. E. (2014). Multivariate Data Analysis. Pearson Education Limited.

Kaiser, H. F. (1974). An index of factorial simplicity. Psychometrika, 39, 31-36.

Katelo, I., Kokina, I., \& Raščevskis, V. (2019). Service quality in the public sector of Latvia. Proceedings of the 61th international scientific conference of Daugavpils University. Part B "Social Sciences”. Daugavpils: Daugavpils University.

Kondrotaite, G. (2012). Evaluation of the quality of public services in Lithuanian municipalities. Intellectual economics, Vol 6, No 3.

Li, H., Edvards, S. M., \& Lee, J-H. (2013). Measuring the Intrusiveness of Advertisements: Scale Development and Validation. Journal of Advertising, 31(2).

Mazur, S., Możdżeń, M., \& Oramus, M. (2018). Public administration characteristics and performance in EU28. Poland, EC, EIPA, Cracow University of Economics.

Melece, L. (2004). Quality management and economics of food on primary and secondary production sphere. Doctoral thesis. Latvian Agricultural University: Jelgava.

Nimako, S., Azumah, F. K., Donkor, F., \& Adu-Brobbey, V. (2012). Confirmatory factor analysis of service quality dimensions within mobile telephony industry in Ghana. The Electronic Journal Information Systems Evaluation, Volume 15, Issue 2, 197-215. Retrieved from: www.ejise.com

Pal, Y. (1986). A Theoretical study of Some Factor Analysis Problems, a paper presented at the IX Annual Conference of the Indian Society for Probability and Statistics held at Delhi. University of Delhi: India.

Pal, Y., \& Bagai, O. P. (1987). A Common Factor Bettery Reliability Approach to Determine the Number of Interpretable Factors, a paper presented at the IX Annual Conference of the Indian Society for Probability and Statistics held at Delhi. University of Delhi: India.

Pallant, J. (2007). SPSS Survival Manual: A Step by Step Guide to Data Analysis Using SPSS for Windows Version 15. Retrieved from: www.researchgate.net

Parasuraman, A., Zeithaml, V. A., \& Berry, L. L. (1988). SERVQUAL: a multiple item scale for measuring consumer perceptions of service quality. Journal of Retailing, vol.64, no.1, 12-40.

Putāns, R. (2016). Role of client-oriented approach in the development of public administration: Case study of youth. Summary of doctoral thesis. Latvian University: Riga.

Sanchez-Perez, M., Gazques-Abad, J. C., \& Sanchez Fernandez, R. (2007). Effects of service quality dimensions on behavioural purchase intentions: A study in public-sector transport. Journal of service theory and practice, 17(2), 134-151.

Tuomi, V. (2012). Quality management in public sector. University of Vaasa: Finland.

Williams, C. S, Saunders, M. N. K. (2008). Improving service quality in the new public sector. The Routledge Nonprofit Marketing Companion. 